made in the systematic application of the theoretical and practical methods of physical chemistry to equilibrium in aqueo-mineral systems at low temperatures. The position reached by 1960 was reviewed by Garrels ${ }^{3}$.

In Complexing and Hydrothermal Ore Deposition, Dr. Helgeson discusses the internal structure of electrolyte solutions at temperatures lying, for the greater part, in the range $25^{\circ}-400^{\circ} \mathrm{C}$. Ho presents the results, obtained by the use of a digital computer, relating to the equilibria of complex formation in multicomponent systems, and is at pains to make clear that present thermodynamic knowledge falls far short of that required for the construction of a complete theory of hydrothermal ore deposition.

Helgeson, nevertheless, makes positive claims. $\mathrm{He}$ believes that his figures demonstrate, at least in the case of lead sulphide (galena), that the metal is carried as chloride complexes in an aqueous fluid containing alkali chlorides, and that the $p H$ of such solutions is near to neutral or somewhat acid. This view will certainly draw the critical interest of the experimentalists.

All geochemists will welcome this contribution, though recognizing it as a progress report. Few geologists will be adequately prepared for the exposition of the principles on which the work is founded. It is much to be regretted that the introductory section of the book could not have been written with this readership more in mind.

The usefulness of a possible second edition would be greatly enhanced by an account of experimental methods used in the investigation of aqueous inorganic solutions at high temperatures; by a fuller discussion of hot-spring and of wall-rock analyses; by a review of relevant geothermometric observations based on isotopic and trace element distributions; by descriptions of chosen examples of metalliferous mineral deposits; and a discussion of the possible ultimate sources of the metals carried by hydro. thermal complexing and also of the alkali chlorides necessary for this. Consideration could also be given to the genesis of the arsenides, sulph-arsenides and oxides frequently found in high-temperature hydrothermal (hypothermal) veins.

The price, $60 s$., is very high for the size of the book. E. D. LACY

' Lindgren, W., Mineral Deposits (McGraw-Hill, 1933).

- Bateman, A. M., Economic Mineral Deposits, second ed. (John Wiley and Sons, 1950).

Garrels, R. M., Mineral Equilibria (Harper, 1960).

\section{ANAXAGORAS REVISITED}

\section{Anaxagoras and the Birth of Physics}

By Daniel E. Gershenson and Daniel A. Greenberg. (A History of Physics: Its Concepts, Methods, and Theories. Series I: Natural Philosophy Before Aristotle.) Pp. $x x v+538$. (New York and London: Blaisdell Publishing Company, a Division of Ginn and Company, 1964.) 10 dollars.

Anaxagoras and the Birth of Scientific Method By Daniel E. Gershenson and Daniel A. Greenberg. Pp. $\mathrm{xv}+63$. (New York and London: Blaisdell Publishing Company, a Division of Ginn and Company, 1964.) 1.45 dollars.

HERE are, apparently inevitably, recurring occasions in the history of scholarship when individuals feel compelled to revolutionize the study of some subject by rejecting traditional views in favour of a totally new approach. So, in fact, do new ideas penetrate the older disciplines. But a contemporary predicts at his peril whether any particular example of such an approach should be praised as useful innovation or damned as blatant impudence.

The authors of Anaxagoras and the Birth of Physics and Anaxagoras and the Birth of Scientific Method-two young Jewish-American scholars, one a classicist and the other a theoretical physicist-are professedly attempting two root and branch revolutions at the same time. They have planned a necessarily vast work, "A History of Physics: Its Concepts, Methods, and Theories", which is to be "a comprehensive history .... intended for laymen as well as professional scientists", to be centred about great figures of the past. The authors do not say in what way they find the history of science as now practised deficient, nor why they feel the need to begin de novo; indeed, they do not use the phrase 'history of science' nor indicate that they are not the first to study physical concepts in historical perspective. In their review of the literature of Anaxagoras they give pretty short shrift to all the historians (half a dozen or so) whom they mention; but in fairness it must be said that they discuss only what relates to Anaxagoras, to whom historians of science have not, in general, devoted great space.

The authors have very properly begun at the beginning and Anaxagoras and the Birth of Physics is a part of Series 1 of their History of Physics, "Natural Philosophy before Aristotle" (Anaxagoras and the Birth of Scientific Method is Part 1 of Anaxagoras and the Birth of Physics, shorn of the more learned footnotes). This reveals the second revolution projected by Drs. Gershenson and Greenberg: an almost total revision of classical scholarship. They reject the work of Diels outright on two grounds: it is not chronologically arranged, and he cites as quotations statements not in Ionic dialect. The first comment is fair enough, and the authors have done a service in providing as Part 2 in their own translations and in chronological order all the statements they could find relating to Anaxagoras, from Plato in the fourth century B.c. to Simplicius in the sixth century A.D. The second criticism seems irrelevant: surely we cannot expect any ancient source to have survived intact, un. altered as to form by copyists and commentators who inevitably 'modernized' even their quotations.

The three parts of the longer work consist, first, of a brief appraisal of Anaxagoras's life and thought; secondly (the bulk of the work), the sources of Anaxagoras's ideas; and thirdly, a tendentious and detailed examination of ancient and modern traditions about Anaxagoras; of the authors cited, Drs. Gershenson and Greenberg place greatest reliance, not unreasonably, on Aristotle. This last part is learned, dogmatic, often characterized by a slightly naïve logic, and vaguely rabbinic in method. It must be for classicists to appraise the reliability of the evidence; they will certainly dislike the practice throughout the book of transliterating Greek-surely a foolish practice of service only to the printer.

The first part of the longer work (and the whole of the shorter) will appeal most to scientists. It is clearly and simply written, in a confident manner; the authors have made up their minds firmly on all relevant points and indulge in none of the doubts or hesitations which laymen find so irritating in the work of specialist scholars. The authors might have helped the reader by explaining the grounds for their prefatory sentence, "Anaxagoras was the first thinker of repute who was a scientist in the sense in which we use the word to-day". For while it is true that Anaxagoras was the first natural philosopher to live and teach in Athens, he had eminent predecessors in the Western Greek world, many of whose concepts, especially those relating to astronomy and cosmology, were more advanced than his. The authors appear to base thoir predilection for Anaxagoras as the first modern physicist on his theory of matter, which they find satisfyingly up to date. Basing their views as they do primarily on what Aristotle had to say about Anaxagoras enables them to fit Anaxagoras snugly into the atomic, logical, realistic, unified and dynamic tradition of physics. What one misses is the placing of Anaxagoras in the content of Greek thought and in the historical pattern of the development of natural philosophy.

Marie Boas Hali 